\title{
"Because It Is $M y$ Culture": Technology and Agency in the Overseas U.S. Cultural History Classroom
}

\section{JoAnne Marie Mancini}

In a 2002 essay in the Journal of American History, Kathryn Kish Sklar made a powerful case, based upon the experience of her own undergraduate seminar in U.S. women's history, for the capacity of the Internet to help address a particular pedagogical concern. Accusing historians of doing "a relatively poor job of explaining their work process to others" and lamenting the fact that most students had little occasion to do more than passively consume secondary literature, Sklar proposed that the Internet-with its capacity to "democratize the availability and analysis of documents"- could lay bare the normally opaque process that historians use to analyze and interpret their sources and thereby assist teachers of history in transforming students into "producers of new historical knowledge." In her own case, Sklar turned her seminar into a laboratory for creating and posting to the Internet "pedagogic units that pose central interpretive questions and provide about twenty primary documents ... annotations of the primary documents, a bibliography, and a list of related Web links." In this way, her students gained a firsthand understanding of historical methods, produced new historical knowledge that other students could use, and disseminated primary sources that were previously available on microfilm in a new and more accessible format. ${ }^{2}$

Like Sklar and many other historians of the United States, I am preoccupied with agency and see it as important to both the writing and the teaching of history. As a cultural historian, my expression of this preoccupation has taken a particular form: the imperative to understand not only works of culture (be they "high" or "low," mass-produced or unique, ephemeral or canonical, or produced by women or men) but also the processes by which people engage and become engaged in the making of such works and the worlds in which those works are made. I wish to understand, in other words, how the particular institutional arrangements within those worlds have facilitated—or discouraged-people's participation in the creation of images and objects. This imperative has also caused me to reconsider the limits of my responsibilities as a researcher. While I began with the assumption that the job of the historian was only to foster historical understanding, my belief that a "good art world is one that foregrounds human capabilities" - a belief developed in response to my historical research-has also led me to make normative claims

JoAnne Marie Mancini is a lecturer in the department of history at the National University of Ireland Maynooth and is currently a visitor in the School of Social Science, Institute for Advanced Study.

Readers may contact Mancini at joanne.mancini@nuim.ie.

' Kathryn Kish Sklar, "Teaching Students to Become Producers of New Historical Knowledge on the Web," Journal of American History, 88 (March 2002), 1471-76. Emphasis added.

2 Ibid., 1474. 
about the "worlds" I study and even to adopt a position of advocacy on behalf of programs that foster artistic creation by nonprofessionals. ${ }^{3}$

This emphasis on agency and process in cultural history is pursued relatively straightforwardly in the context of research and writing. In the cultural history classroom, however, the pursuit presents immediate and difficult challenges. There, students are frequently cast as the inert recipients of secondary literature or as the more or less submissive consumers of cultural works from the American past. This is the case even as many of us have emphasized the analysis of the institutions and processes that underpin cultural production, and even as we have defined the works and the pasts that belong to "American cultural history" in ever-broadening terms (in my case, to include sources on precontact Cahokia, Chaco Canyon, and Hawaii; colonial New Spain, "the middle ground," and the African Atlantic; and material culture, popular music, and digital media).

Such redefinitions of the content of cultural history are important; students in courses with broadened content leave with a wider sense of the temporal and geographic boundaries of the American past and of the disciplinary borders of American historiography. However, such redefinitions do not represent a fundamental pedagogical change toward the creation of more active learners in the cultural history classroom. For that to happen, it is necessary to implement strategies that cast students in active roles: as the creators of historical knowledge or-even more radically-as the makers and performers of other cultural forms beyond the historiographical. While the main purpose of teaching cultural history may be the analysis of the cultures of the past, the creation and performance of culture in the present can also play a significant and beneficial role within the teaching of cultural history.

My experience of living and teaching American cultural history outside of the United States has had a direct bearing on my adoption of this perspective. Over the course of more than a decade spent primarily in Ireland (at the National University of Ireland Maynooth and in the Department of History at University College Cork) but also in the Department of American Studies at the University of Sussex, I have wrestled repeatedly with the dynamics of the complex and interesting relationships that the people around me--both students and nonstudents - have with American history and culture. I choose the word "relationships" deliberately, not least because many Irish people's palpable enthusiasm for American culture is subject to the kinds of ebbs and flows that characterize human relationships; indeed, it would not be misleading to suggest that the giddy upsurge of media and individual interest in all things American after the Barack Obama presidential campaign and election is like the rediscovery of an old love after a period of bitter estrangement. ${ }^{4}$

But the word "relationships" is also appropriate insofar as the interest of many people in Ireland in American culture has been forged through direct, personal, and complex encounters with the United States, Americans, and the objects, artifacts, practices, and forms of American culture. Even after many years of residence in Ireland, friends, colleagues, acquaintances, and strangers still present to me-ofren with great flourish-tales that interweave human migration and cultural exchange in unpredictable ways. An avid

3 J. M. Mancini, "Worlds," American Art, 23 (Spring 2009), 18-19. Examples of advocacy include submissions to Ireland's Arts Council and its National Economic and Social Forum.

4 A good example is Irish television personality Kathryn Thomas's interview on the Tubridy Show. "Kathryn Thomas Interview," prod. Yvonne Judge, Deirdre Ní Fhloinn, and Aonghus McAnally (episode of The Tubridy Show), RTÉ Radio 1 (Jan. 16, 2009). 
fan of the television series The Wire, for example, told me that the very first book he remembers reading was a paperback copy of One Flew Over the Cuckoo's Nest (1962) that an emigrant aunt had "borrowed" from a Veterans Administration hospital in Queens, New York. Meanwhile, an admirer of old-time music recounted with some amusement how, in the cold and damp of his Limerick youth, he had been forced to wear lurid shortsleeved Hawaiian shirts because a relative in California persistently shipped them home to Ireland.

While these two examples fall loosely under the category of the consumption of American culture, other stories indicate the participation of Irish people in the performance and production of American culture as well. This might be summed up by the response that one of my recent students-who is both Irish and French-gave to my usual query to students about why they were taking my course. He said, "because it is my culture." I assumed, in the first instance, that he was referring to the fact that he, as a European, was surrounded by American images, music, and words, or that he personally had a particular fondness for certain American authors or artists. To a certain extent, this assumption was correct: his tastes in novels run to Cormac McCarthy and Don DeLillo. But, as he told me, his response also meant that he was an avid player of the blues guitar. As such, his claim upon American culture and American cultural history derived from his participation as a willing link in the ongoing creation of a global American culture. ${ }^{5}$

This is not the only example, even from my most recent group of students in HY383 (a final-year elective in American cultural history in which students write a research essay and complete a project). Another student has devoted several decades to organizing amateur musical theater productions with adult and youth groups. She observed that many, if not most, of these musicals - and even the genre itself-are American; the practices and institutions involved in staging them as amateur productions also have strong historical and current American links. Moreover, as she notes, the adaptation and transplantation of these "American" works into mid-twentieth-century Ireland-a context very different from that of their original staging and subject to different kinds of censorship and pressure-involved the explicit choice of adopting "American" attitudes toward what was culturally and socially permissible on the public stage.

My students' prior experience with and interest in culture making and their attraction to the study of American cultural history presented me with a tremendous opportunity but also posed a daunting challenge. How could we harness these qualities in the classroom, to aid historical analysis and to encourage active citizenship in the republic of culture? A previous experiment I had undertaken at the University of Sussex to transform classroom consumers into producers and performers had not turned out well. Departing from normal classroom procedures, I had required students in a seminar on the American dream (a course whose title and theme I had unwillingly inherited) to script, rehearse, direct, perform, and review a stage version of Theodore Dreiser's Sister Carrie (1900). This experience did have some positive results: students developed a deeper understanding of the text, of the complexity of the theatrical world, and of the Gilded Age. Nonetheless, this came at the cost of nearly causing a riot in a class that was extremely resistant to doing anything but sitting around talking.

\footnotetext{
5 There are even more complex layers to such a process, owing to the rise of immigration in Ireland and the growth of immigrant professional, social, and cultural associations. Filipinos in Ireland, for example, have developed many such organizations, including the Filipino Sports Club (a Dublin basketball league). In this case, one can see immigrants transplanting a cultural practice that is Filipino, but whose origins can be traced to U.S. occupation.
} 
At the National University of Ireland Maynooth, I decided to try something different, inspired by the fact that I-like Sklar and so many others - had become enchanted by the Internet's many cultural possibilities within and outside of the classroom. Perhaps not surprisingly, I have been drawn to Web sites that promote active engagement in the making, performance, transmission, and transformation of culture (present and past). One of the most interesting of such Web sites, from the vantage point of access to sources and from the perspective of cultural history, is LibriVox (http://librivox.org). Established in August 2005 by the Montreal-based writer and Web developer Hugh McGuire, LibriVox aims to publish downloadable digital audio files of every book in the public domain. More important, the Web site is entirely noncommercial: it accepts no advertising and is run entirely by volunteers who manage the site (including the index and boards) and choose, record, and disseminate its ever-growing list of books to anyone with computer access. In short, LibriVox is a new kind of cultural phenomenon: a giant, global, virtual meeting place for people who love books, who are interested in making performances of the books they love, and who are willing to use new technologies to turn those performances into permanent recordings that will allow others to share that love of books. As such, it is itself historically important and undoubtedly will present to future historians all sorts of analytical questions about production, consumption, and agency, about how the Internet presents opportunities for institutional innovation in the realm of culture, and about the boundaries between oral and literary cultures in a digital age.

LibriVox (along with slightly different sites such as YouTube) has become a subject for analysis by my cultural history students, who have already considered earlier revolutions in media and culture, such as the emergence of photography, moving pictures, radio, and recorded sound. But it has also become the inspiration for an important feature of my course: an assignment in which students create digital audio recordings of sources relevant to the study of American cultural history and present a contextual analysis of those recordings to the class.

Because it was my original intention that students would post their recordings on LibriVox, I initially required students to choose sources that conformed to the Web site's public domain requirements and that would be technically manageable in terms of length: short texts published before 1923, such as speeches, poems, letters, short stories, critical commentaries, and essays; monologues or dialogues from the theatre; or songs from sheet music. I was conscious that such parameters would limit my students' choices, but many of them were able to find sources of interest to them even within the artificial boundaries I had set. Some students appeared to have chosen their sources completely at random, but others had clear analytical or personal motivations for the choices they had made. One student selected an excerpt from the novel Tom Sawyer (1876) that reminded him of having heard Mark Twain's work read to him as a child. Another student with an interest in civil religion chose to speak the words of George Washington-in female, French-accented tones. And a student with acting aspirations performed both sides of a comic minstrel routine with a combination of embarrassment and flair.

Nonetheless, other students immediately pushed against the boundaries I had set, seeking to exercise a greater degree of autonomy as performers and producers. One student wanted to "be" Colonel Kurtz from the film Apocalypse Now (1979). One wanted to perform a T. S. Eliot poem that was still covered by copyright-and to add sound effects. One wanted to appeal to the "silent majority" in the words of Richard M. Nixon. 
Perhaps not surprisingly, given what I have said above, one wanted to direct scenes from the play Fiddler on the Roof and another wanted to abandon texts altogether and play the blues guitar. Although I could not let such recordings go live into cyberspace, how-for the purposes of the assignment-could I say no?

From the very beginning, the implementation of this project required technical assistance and equipment that is not normally available to history faculty. Indeed, even before discovering LibriVox, I had considered trying to pilot an audio project in my course, but had run up against a lack of equipment. Luckily, on a second attempt I was able to collaborate with the university's learning technology officer, Lisa O'Regan. She has admirably trained my students to download and use Audacity (a free software program) so that they can make and edit recordings to an appropriate standard. She has facilitated access to scarce equipment (microphones, digital audio recorders, and computers) and recording space, and she has provided ongoing technical and logistical support.

Unlike my earlier experiment at the University of Sussex, this experience has been almost entirely successful. The quality of the final essays in the course improved after the introduction of the audio project. The students learned to use a new technology that they may use in other areas of their lives. And they have been confirmed in their roles as cultural performers, creators, critics, and historians. Indeed, since completing the first round of the project I have seen one of my students on television and heard another on the radio-an entirely new and unexpected development. The only hitch is that in loosening the requirements for sources to accommodate student interests, it became necessary to drop the requirement that students post their recordings on LibriVox. While I have made this a voluntary aspect of the assignment, students have thus far been disinclined to post their recordings even when their sources have fallen within the Web site's rules. But this issue can be addressed as the project evolves.

Like Kathryn Kish Sklar, I have found that a key strategy for addressing the pedagogical and ideological issue of transforming students from consumers into producers is to join that pursuit to the employment of a new technology. Students are interested in new technologies and desire mastery over them. Thus in part because they were gaining a measurable skill that they would not normally have obtained in their history studies-competence in the use of digital audio software-my students in Maynooth have been much less resistant than my earlier students to the idea of creating performances. Of course, other factors also explain the willingness and enthusiasm that many of them showed. The general university culture in Maynooth encourages ongoing participation in creative activities; whether one is teaching U.S. cultural history or some other subject, one is likely to have a few playwrights, filmmakers, set designers, or musicians in class. Maynooth also has a large number of "mature" students, who have not entered the university directly from secondary school and who in many cases have begun their higher education significantly later in life. Such students tend to be engaged and ambitious, and-while they sometimes require more assistance with technical matters-are also sometimes less reluctant to take on unusual tasks than the youngest students. Moreover, in Irish universities virtually all students take "joint honours" (a double major). Thus in Maynooth one is likely to have at least a few students who are also taking media studies, music, or other subjects in which creative or studio work is expected. To this mix are added large numbers of international students from as close as England and as far away as the French Indian Ocean départment of Réunion-with well over one hundred of them taking courses in 
the history department last year. A number of them from the more overburdened European universities have told me that their home institutions offer virtually no opportunity for personal attention and training or for expression outside the normal boundaries of the academic examination or essay.

Thus it has been possible, with my university's support, to provide my students with a pedagogical experience that is empowering, innovative, and practical. I would like to think that all of these things are imperatives of " $m y$ culture" - and should be goals in the teaching of U.S. cultural history. I hope to keep this and other experiments running for years to come. 
Copyright of Journal of American History is the property of Organization of American Historians and its content may not be copied or emailed to multiple sites or posted to a listserv without the copyright holder's express written permission. However, users may print, download, or email articles for individual use. 